\title{
PENGUJIAN KENDARAAN BERMOTOR UNTUK MEWUJUDKAN KESELAMATAN BERLALU LINTAS DI KOTA DENPASAR
}

\author{
Oleh: \\ Putu Lantika Oka Permadhi ${ }^{1}$
}

\begin{abstract}
Transportation plays an important role in supporting, improving and enhancing the economic development both regionally and nationally. The need for services is increasing traffic, limiting the number of motor vehicles as much growing from year to year in Denpasar City causes unbalance between the number of vehicles available with the road infrastructure are available and also increase the traffic accident per year. Accidents in the road are usually caused by motor vehicles. In this case largely due to technical factors and not roadworthy. The issues examined are how is the implementation of the motor vehicle feasibility test in Denpasar City and whether is the implementation of vehicle testing already able to realize the safety of traffic in Denpasar City. The research was classified into empirical legal research of the descriptive analysis research using primary and secondary data.
\end{abstract}

Keywords : Traffic, Transportation, Motor Vehicle Testing

\begin{abstract}
Abstrak
Transportasi memainkan peran penting dalam mendukung, memperbaiki dan meningkatkan pembangunan ekonomi baik di tingkat regional maupun nasional. Kebutuhan akan layanan lalu lintas semakin meningkat, jumlah kendaraan bermotor bertambah daritahun ketahun di Kota Denpasar sehingga menyebabkan ketidakseimbangan antara jumlah kendaraan yang dengan infrastruktur jalan danjuga meningkatkan kecelakaan lalu lintas per tahun. Kecelakaan yang terjadi di jalan biasanya disebabkan oleh kendaraan bermotor, dalam hal ini sebagian besar dikarenakan dari faktor teknis dan tidak layakjalan. Permasalahan yang diteliti adalah Bagaimana pelaksanaan uji kelayakan kendaraan bermotor di Kota Denpasar dan Apakah pelaksanaan pengujian kendaraan bermotor sudah dapat mewujudkan keselamatan berlalu lintas di Kota Denpasar. Penelitian ini diklasifikasikan ke dalam penelitian hukum empiris dari penelitian analisis deskriptif dengan menggunakan data primer dan data sekunder.
\end{abstract}

Kata Kunci : Lalu Lintas, Transportasi, Pengujian Kendaraan Bermotor

1 Staf Dinas Perhubungan Kota Denpasar, email: lantikaokap@yahoo.com 


\section{PENDAHULUAN}

Kehidupan sebuah kota tidak dapat dilepaskan dari kebutuhan akan berbagai sarana dan prasarana layanan publik sebagai pendukung kebutuhan masyarakat. ${ }^{2}$ Pertumbuhan yang pesat dari populasi perkotaan berdampak terhadap kebutuhan sarana dan prasarana. Salah satu sarana dan prasarana layanan publik yang ada adalah lalu lintas, yang dimana merupakan sebuah sarana komunikasi masyarakat dan mempunyai peran penting dalam memperlancar pembangunan. Dengan begitu memudahkan adanya akses pada masyarakat untuk melaksanakan berbagai kegiatan serta untuk pemenuhan perekonomian.

Salah satu unsur penting pada lalu lintas yaitu transportasi, yang dimana transportasi ini sangat mendukung kegiatan dan perputaran roda pembangunan nasional terutama pada bidang perekonomian seperti perdagangan dan industri. Dalam kegiatan perdagangan dan industri, sarana dan prasarana sangat diperlukan untuk mendukung aktivitas di kawasan kota. ${ }^{3}$ Kawasan kota merupakan tempat

2 Pontoh, Nia Kurniasih dan Iwan Kustiawan, 2009, Pengantar Perencanaan Perkotaan, Intitut Teknologi Bandung (ITB), Bandung, hlm. 108.

3 Ainun Nazifah dan Ernawati, Kinerja Dinas Perhubungan Komunikasi dan Informastika Kota Pekanbaru Dalam Melakukan Pemeriksaan Angkutan Kota (Uji Kir), Fisip Universitas Riau, https:// jom.unri.ac.id/index.php/JOMFSIP/ article/view-File/2214/2156, diakses pada tanggal 3 September 2017. berbagai kegiatan masyarakat dengan segala aktivitasnya. Oleh sebab itu, banyak orang yang menginginkan adanya sebuah kenyamanan dalam bertransportasi, sehingga kemajuan teknologi yang ada menjadi sebuah tuntutan besar. Dengan adanya kemajuan teknologi pada transportasi, perkembangan lalu lintas dan angkutan jalan menjadi lebih meningkat dari sebelumnya.

Kendaraan bermotor yang merupakan salah satu komponen sarana transportasi yang sangat penting bagi perkembangan kegiatan perekonomian, sosial dan kebudayaan suatu negara karena kendaraan bermotor ini mempunyai peran sebagai alat pergerakan orang dan/atau barang dari suatu wilayah ke wilayah lain dengan waktu yang relatif singkat, efisien dan efektif.

Oleh sebab itu, dalam konteks pergerakan barang dan jasa dapat disimpulkan bahwa transportasi merupakan salah satu mata rantai terpenting dalam pembangunan dan pemeliharaan jaringan-jaringan distribusi. Sedangkan dalam konteks pergerakan orang, transportasi berperan sebagai sarana dalam pengisi kehidupan sosial, ekonomi, kebudayaan dan politik masyarakat. Dengan demikian, transportasi dapat dikatakan sebagai salah satu unsur penting untuk memajukan kehidupan masyarakat. Pengertian transportasi secara sederhana didefinisikan sebagai pemindahan muatan barang atau 
manusia dari satu tempat atau wilayah ke tempat atau wilayah lainnya sebagai tujuan. Dimana dalam pelaksanaan transportasi itu diatur oleh undangundang dengan tujuanmewujudkanlalu lintas, angkutan jalan, perkeretaapian, penerbangan dan pelayaran dengan selamat, aman, cepat, lancar, tertib dan teratur, nyaman dan efisien, mampu memadukan transportasi lainnya, menjangkau seluruh pelosok wilayah daratan untuk menunjang pemerataan, pertumbuhan dan stabilitas sebagai pendorong, penggerak dan penunjang pembangunan nasional dengan biaya yang terjangkau oleh daya beli masyarakat. Pada kenyataannya pelayanan angkutan barang dan orang yang tidak memadai merupakan kontributor utama padatnya lalu lintas jalan raya sehingga menyebabkan adanya tuntutan pelayanan yang lebih baik. Transportasi ini juga sangat berkontribusi pada penurunan dari kualitas udara luar ruangan yang menyebabkan terjadinya penyakit pernapasan terutama pada daerah dengan kepadatan lalu lintas yang luar biasa, banyaknya kecelakaan yang terjadi di jalan raya, berkontribusi juga pada deplesi sumber enegi yang tak terbarukan, serta juga pada pelepasan gas rumah kaca yang masif akibat dari pembakaran bahan bakar yang tak terbarukan.

Dengan alasan tersebut, tidaklah mengherankan bila di beberapa daerah terutama dikota-kota besar telah ditetapkan ketentuan dan peraturan berlalu lintas di jalan raya yang mempunyai tujuan untuk dapat memastikan adanya keamanan dan kenyamanan dalam berkendara, serta adanya perlindungan pada konsumen dan juga untuk pelestarian pada fungsi lingkungan hidup. Penyelenggaraan lalu lintas dan angkutan jalan yang menggunakan kendaraan bermotor seharusnya mampu menjamin daya jangkau dan pelayanan dengan memperhatikan keselamatan umum, terciptanya keamanan dan ketertiban masyarakat dalam berkendara serta untuk kelestarian pada lingkungan sekitar. Kendaraan bermotor yang digunakan dijalan harus selalu memenuhi adanya persyaratan teknis dan laik jalan, termasuk adanya persyaratan ambang batas emisi gas buang dan kebisingan. Pada dasarnya, persyaratan teknis dan laik jalan ini diberlakukan wajib bagi seluruh kendaraan yang beroperasi dijalan. Namun dalam Peraturan Pemerintah Nomor 55 Tahun 2012 tentang Kendaraan, hanya jenis kendaraan penumpang umum dan barang yang diwajibkan untuk melakukan pemeriksaan pengujian kendaraan bermotor. Pengujian kendaraan bermotor secara umum dilaksanakan selain dalam rangka menjamin keselamatan dan pelayanan umum, juga merupakan salah satu upaya untuk memperbaiki kualitas udara di luar ruangan terutama di jalan raya serta permukiman yang berada pada lintasan angin yang berasal dari jalan 
raya. Menyadari pentingnya peranan transportasi dalam berlalu lintas di jalan, maka pemerintah harus menata lebih baik sistem transportasi nasional secara terpadu dan juga mampu mewujudkan jasa transportasi yang tertib, nyaman, teratur, cepat, lancar dan dengan biaya yang terjangkau sehingga kebutuhan akan lalu lintas dan pelayanan angkutan yang nyaman dapat diwujudkan. Oleh sebab itu, pemerintah telah mengeluarkan kebijakan pada bidang transportasi darat yaitu dikeluarkannya UndangUndang Nomor 22 Tahun 2009 tentang Lalu Lintas dan Angkutan Jalan (selanjutnya disebut UU 22/2009) yang dimana pelaksanaannya khususnya dalam menjalankan pelayanan pengujian kendaraan bermotor merupakan langkah preventif.

Dengan menyadari pentingnya peranan transportasi, maka lalu lintas dan angkutan jalan harus ditata dalam suatusistemtransportasinasionalsecara terpadu dan mampu mewujudkan tersedianya jasa transportasi yang sesuai dengan tingkat kebutuhan lalu lintas dan pelayanan angkutan yang tertib, nyaman, cepat, teratur, lancar dan dengan biaya yang terjangkau oleh daya beli masyarakat. Untuk itu pemerintah telah mengeluarkan kebijakan di bidang transportasi darat yaitu dengan dikeluarkannya UU No. 22 Tahun 2009 tentang Lalu Lintas dan Angkutan Jalan (selanjutnya disebut UU 22/2009). Pelaksanaan UU 22/2009, khususnya dalam menjalankan pelayanan pengujian kendaraan bermotor merupakan langkah preventif.

Berdasarkan ketentuan UU 22/2009, telah diwajibkan bagi setiap kendaraan bermotor yang dioperasikan di jalan harus dilakukan pengujian. Namun mengingat keterbatasan fasilitas dan peralatan pengujian yang ada, maka kewajiban uji tersebut saat ini masih dibatasi pada jenis kendaraan bermotor tertentu saja, yaitu mobil barang, mobil bus, kendaraan khusus dan angkutan umum. Jenis-jenis kendaraan tersebut yang wajib untuk pemeriksaan dan pengujian laik jalan kendaraan yang dilakukan setiap 6 (enam) bulan sekali. Dinas Perhubungan harus mengoptimalkan pelayanan pengujian kendaraan bermotor. Dewasa ini, pelayanan pengujian kendaraan bermotor ini dirasakan cukup penting dalam tatanan penyelenggaraan pemerintah pada bidang perhubungan khususnya transportasi darat, maka dari itu Dinas Perhubungan selalu dituntut memberikan pelayanan yang baik kepada pengguna kendaraan bermotor supaya para pengguna kendaraan tersebut mau melakukan uji kelayakan kendaraan. Pelayanan kepada masyarakat ini memerlukan adanya kinerja yang baik dalam pelayanan publik sehingga tercipta tujuan yaitu adanya kepuasan dari para pengguna jasa pengujian kendaraan bermotor. Transportasi saat ini lebih mengutamakan pada 
pelayanan jasa orang dan barang kepada konsumennya, dan untuk mendapatkan konsumen tersebut harus mempunyai ijin untuk layak berada di jalan sebagai tempat pengujian kendaraan/transportasi. Pelayanan pengujian kendaraan bermotor adalah pemeriksaan pada kondisi kendaraan yang dilakukan oleh petugas yang berwenang dalam hal ini disebut penguji. Penguji ini akan menentukan apakah kendaraan yang diuji tersebut telah memenuhi persyaratan laik jalan atau tidak, termasuk juga kelengkapan surat-surat kendaraan bermotor yang merupakan kewenangan dari Perhubungan. Dari pemeriksaan kondisi kendaraan bermotor tersebut, maka sangat dibutuhkan pelayanan dalam kelancaran pengujian kendaraan bermotor itu sendiri. Isu di bidang transportasi adalah permasalahan mengenai banyaknya kecelakaan lalu lintas yang terjadi dan masalah lingkungan. Salah satu faktor yang mempengaruhi kecelakaan lalu lintas adalah kondisi padakendaraan. Dengan demikian, dalam upaya menekan jumlah kecelakaan yang terjadi di jalan serta untuk pengendalian masalah lingkungan, langkah yang dilakukan adalah melalui pengujian kendaraan bermotor.

Salah satu fungsi utama pemerintah adalah untuk melaksanakan kegiatan pembangunan serta pelayanan kepada masyarakat sebagai bentuk tugas umum untuk mewujudkan adanya kesejahteraan. ${ }^{4}$ Oleh sebab itu, Dinas Perhubungan Kota Denpasar berusaha membuat sebuah sistem transportasi dimana masyarakat dapat merasa nyaman dalam berkendara dengan cara meningkatkan penyediaan sarana, prasarana dan fasilitas perhubungan yang bertujuan untuk mengurangi kecelakaan lalu lintas dan menghindarkan masyarakat dari kesesatan dalam perjalanan, meningkatkan kualitas pelayanan angkutan umum dengan memberikan sosialisasi pada kru angkutan tentang UU 22/2009, menciptakan masyarakat Kota Denpasar yang lebih informatif dan komunikatif dengan cara penyebaran informasi secara cepat dan akurat sehingga dapat terjalin hubungan yang sinergi antara masyarakat dengan Pemerintah Kota Denpasar untuk meningkatkan partisipasi masyarakat dalam pembangunan. Mengacu pada Pasal 48 UU 22/2009 secara tegas menjelaskan mengenai kendaraan bermotor yang beroperasi dijalan harus memenuhi persyaratan teknis yang meliputi susunan, perlengkapan, ukuran, karoseri, rancangan teknis kendaraan sesuai dengan peruntukannya, pemuatan, penggunaan, penggandengan kendaraan bermotor dan/atau penempelan kendaraan bermotor serta

4 Otovinur Dwi Chantika, 2013, Kinerja Organisasi UPTD Pengujian Kendaraan Bermotor Wiyung Kota Surabaya, Volume 1 Nomor 1 Januari 2013, http://juornal.unair. ac.id/download-fullpapers-2\%20Otovinur $\% 2$ 0KMP\%20VI\%20NI\%20Jan-April\%202013. pdf, diakses pada tanggal 3 September 2017. 
persyaratan laik jalan meliputi emisi gas buang, kebisingan suara, efisiensi sistem rem utama, efisiensi sistem rem parkir, kincup roda depan, suara klakson, daya pancar dan arah sinar lampu utama, radius putar, akurasi alat penunjuk kecepatan, kesesuaian kinerja roda dan kondisi ban dan kesesuaian daya mesin penggerak terhadap berat kendaraan. Apabila melihat fakta dijalan terkait kondisi fisik dimana sebagian besar angkutan penumpang maupun angkutan barang jauh dari kata layak. Seringkali ditemui angkutan penumpang yang mogok di pinggir jalan sehingga mengganggu kenyamanan berkendara ataupun kondisi kendaraan yang seharusnya tidak laik jalan. Keadaan seperti ini akan menjadi masalah dengan posisi Kota Denpasar yang sangat strategis tersebut menyebabkan pergerakan arus transportasi yang terjadi sangat padat. Selain itu fakta yang sering ditemui di jalan adalah penyimpangan pengoperasian angkutan umum yang melebihi kapasitas, yaitu banyak penumpang yang dalam 1 (satu) kendaraan melebihi kapasitas yang ada pada angkutan umum ataupun penumpang harus bertahan dalam kondisi apapun di dalam bus, setidaknya di pintu bus asal terangkut serta banyaknya kejadian kecelakaan lalu lintas yang diakibatkan oleh rem blonk. Dengan demikian seharusnya setiap kendaraan yang beroperasi dijalan diwajibkan untuk melakukan pemeriksaan kendaraan bermotor nya. Berdasarkan uraian-uraian diatas, dengan demikian penulis tertarik mengadakan penelitian dan menuangkannya dalam penulisan hukum dengan judul: "PENGUJIAN KENDARAAN BERMOTOR UNTUK MEWUJUDKAN KESELAMATAN BERLALU LINTAS DI KOTA DENPASAR".

Dengan latar belakang tersebut diatas, adapun permasalahan yang dapat dikaji dalam artikel ini, yaitu:

1. Bagaimana pelaksanaan uji kelayakan kendaraan bermotor di Kota Denpasar?

2. Apakah pelaksanaan pengujian kendaraan bermotor sudah dapat mewujudkan keselamatan berlalu lintas di Kota Denpasar? Penelitian ini adalah karya ilmiah asli yang belum pernah diteliti sebelumnya. Adapun karyailmiahyang terkait dengan karya ilmiah Penulis tentangPengujian KendaraanBermotor Untuk Mewujudkan Keselamatan Berlalu Lintas di Kota Denpasar yaitu karya ilmiah dari Ida Bagus Komang Surya Dharma Putra dan Agoes Ganesha Rahyuda tahun 2015 dengan judul Pengaruh Lingkungan Kerja Fisik dan Stres Kerja Terhadap Kinerja Pegawai UPT. Pengujian Kendaraan Bermotor Dinas Perhubungan Kota Denpasar yang rumusan masalahnya adalah bagaimana hubungan antara lingkungan kerja fisik, stres kerja, dan kinerja pada konteks organisasi 
pelayanan publik yang melayani jasa pengujian kendaraan bermotor dengan sistem drive thru di Kota Denpasar?. ${ }^{5}$ Karya ilmiah lainnya yang terkait yaitu I Made Aditya Wiryadarma dan I Gusti Ngurah Wairocana tahun 2015 dengan judul Penegakan Peraturan Daerah Kota Denpasar Nomor 26 Tahun 2001 tentang Penyelenggaraan Pengujian Kendaraan Bermotor yang rumusan masalahnya adalah bagaimana pelaksanaan pengujian kendaraan bermotor berdasarkan UU No. 23 Tahun 2014 ? dan faktor-faktor apa yang menyebabkan terhambat nya pelaksanaan pengujian kendaraan bermotor di Kota Denpasar ?. ${ }^{6}$ Tampak jelas adanya perbedaan dari karya ilmiah tersebut dengan karya ilmiah yang dibuat oleh Penulis. Keunggulan karya ilmiah ini dari karya ilmiah lainnya yaitu membahas lebih dalam tentang pelaksanaan uji kelayakan kendaraan bermotor di Kota Denpasar dan apakah dengan melakukan pengujian kendaraan bermotor sudah

5 Ida Bagus Komang Surya Dharma Putra dan Agoes Ganesha Rahyuda, Pengaruh Lingkungan Kerja Fisik dan Stres Kerja Terhadap Kinerja Pegawai di UPT. Pengujian Kendaraan Bermotor Dinas Perhubungan Kota Denpasar, E-Jurnal Manajemen Unud, Vol. 4, No. 9, 2015: 2491-, https:// ojs,unud.ac.id/index.php/Manajemen/article/ view/12895/10301, diakses pada tanggal 3 September 2017.

6 I Made Aditya Wiryadarma dan I Gusti Ngurah Wairocana, Penegakkan Peraturan Daerah Kota Denpasar Nomor 26 Tahun 2001 Tentang Penyelenggaraan Pengujian Kendaraan Bermotor, E-Jurnal Manajemen Unud, Vol. 3, No. 3, 2015, https://ojs,unud.ac.id/index. php/Kerthanegara/article/view/15203, diakses pada tanggal 3 September 2017. dapatmewujudkan adanyakeselamatan berlalu lintas.

Dengan melihat latar belakang masalah diatas, tujuan umum dari penelitian ini adalah untuk memahami pelaksanaan uji kelayakan kendaraan bermotor di Kota Denpasar sehingga masyarakat dapat mengetahui bagaimana proses dan pelaksanaan pelayanan dalam melakukan uji kendaraan bermotor.

Sesuai dengan permasalahan yang dikaji, maka tujuan khusus dari penelitian ini, adalah :

1. Untuk mengetahui dan menganalisis pelaksanaan uji kelayakan kendaraan bermotor di Kota Denpasar.

2. Untuk menganalisis pelaksanaan pengujian kendaraan bermotor dalam upaya mewujudkan keselamatan berlalu lintas di Kota Denpasar.

\section{METODE PENELITIAN}

Jenis penelitian ini adalah penelitian hukum empiris. Penelitian hukum empiris merupakan penelitian tentang fakta-fakta sosial masyarakat atau fakta-fakta berlakunya hukum di masyarakat. ${ }^{7}$ Dalam penelitian ini, sifat penelitian yang digunakan deskriptif analisis yaitu dapat menggambarkan secara tepat, rinci, sistematis dan menyeluruh serta menggunakan cara dengan menganalisis data yang diperoleh yang berkaitan dengan

7 Bahder Johan Nasution, 2008, Metode Penelitian Ilmu Hukum, Mandar Maju, Bandung, hlm. 135. 
permasalahan sehingga mendapatkan gambaran yang jelas. ${ }^{8}$

Data yang digunakan dalam penelitian ini diperoleh dari dua sumber data, yaitu :

1. Sumber Data Primer (data lapangan), yakni data yang diperoleh terutama dari hasil penelitian empiris, yaitu penelitian yang dilakukan langsung di masyarakat. ${ }^{9}$ Data yang diperoleh didapatkan secara langsung melalui teknik wawancara dengan informan dan responden.

2. Sumber Data Sekunder, adalah data yang diperoleh dari kepustakaan yaitu dengan meneliti bahan-bahan hukum.

\section{HASIL DAN PEMBAHASAN}

\subsection{Pengertian \\ Kendaraan Bermotor}

Pengujian kendaraan bermotor adalah serangkaian kegiatan menguji atau memeriksa kendaraan bermotor, kereta gandengan, kereta tempelan dan kendaraan khusus untuk mewujudkan adanya pemenuhan terhadap persyaratan teknis dan laik jalan. ${ }^{10}$ 8 Ni Made Anggia Paramesthi Fajar, Pelaksanaan Peraturan Daerah Provinsi Bali No 5 Tahun 2008 Tentang Pramuwisata di Kabupaten Badung, Jurnal Magister Hukum Udayana (Udayana Master Law Journal), vol. 4 no. 2 edisi Juli 2015, hlm. 344.

9 Mukti Fajar \& Yulianto Achmad, 2010, Dualisme Penelitian Hukum Noramtif \& Empiris, Pustaka Pelajar, Yogyakarta, hlm. 157.

10 Daniel, Studi Tentang Pelayanan dan Pengujian Kelaikan Kendaraan Bermotor di UPT. Pengujian Kendaraan Bermotor Dinas Perhubungan Kota Samarinda, eJournal Administrasi Negara, 2013, 1 (4): 1554-
Pengujian kendaraan motor inijuga bisa disebut uji kir. Berdasarkan Peraturan Pemerintah Republik Indonesia Nomor 55 tahun 2012 tentang Kendaraan pada Pasal 146 yang menyebutkan pengujian kendaraan bermotor dilakukan secara berkala enam bulan sekali dalam rangka menjamin adanya keselamatan masyarakat dan kelestarian lingkungan.

Pemilik kendaraan wajib untuk mendaftarkan kendaraan bermotor nya untuk pengumpulan data yang digunakan untuk tertib administrasi, pengendalian kendaraan bermotor yang beroperasi, mempermudah penyelidikan pelanggaran atau kejahatan yang menyangkut kendaraan yang bersangkutan, serta dalam rangka perencanaan, rekayasa dan manajemen lalu lintas dan angkutan umum serta untuk memenuhi kebutuhan data lainnya dalam rangka perencanaan pembangunan nasional. Pelaksanaan pengujian kendaraan bermotor dilakukan pada Unit Pengujian Kendaraan Bermotor dan dijalankan oleh penguji yang memenuhi persyaratan yang ditetapkan oleh pemerintah. Bagi kendaraan yang sudah memenuhi persyaratan kelaikan jalan akan disahkan oleh pejabat yang ditunjuk dan diberikan tanda uji. Sasaran pengujian ini meliputi kegiatan memeriksa, menguji, mencoba dan

1568, http://ejournal.an.fisip-unmul.ac.id/ site/wpcontent/uploads/2013/11/02_format artikel_ejournal_mulai_hlm_genap\% $\% 20(11-$ 27-13-07-00-58.pdf, diakses pada tanggal 3 September 2017. 
meneliti yang diarahkan kepada setiap kendaraan bermotor wajib uji secara keseluruhan pada bagianbagian kendaraan secara fungsional dalam sistem komponen dan dimensi teknisnya baik maupun berdasarkan persyaratan teknis yang objektif.

Pelayanan pengujian kendaraan bermotor ini juga merupakan salah satu obyek retribusi jasa umum. Obyek retribusi jasa umum adalah suatu pelayanan yang diberikan oleh pemerintah baik pusat maupun daerah yang bertujuan untuk kepentingan dan kemanfaatan umum serta dapat dinikmati oleh pribadi maupun badan. ${ }^{11}$ Sebagaimana dimaksud dalam jenis-jenis retribusi jasa umum huruf (g) pelayanan pengujian kendaraan bermotor ini sudah sesuai dengan peraturan perundang-undangan yang berlaku yang diselenggarakan oleh pemerintah pusat maupun daerah. ${ }^{12}$

Penguji dalam pelaksanaan pengujian kendaraan bermotor kendaraan bermotor merupakan pegawai negeri sipil yang diberikan tugas, tanggung jawab, wewenang dan hak secara penuh oleh pejabat berwenang untuk melakukan tugas menguji kendaraan bermotor dan mempunyai sertifikat kompetensi dan kualifikasi teknis penguji kendaraan bermotor. Kendaraan bermotor di sini adalah kendaraan yang digerakkan dengan peralatan teknik dimana peralatan tersebut merupakan satu

11 Nurlan Darise, 2006, Pengelolaan Keuangan Daerah. PT. Indeks, Jakarta, hlm. 72.

12 Ibid, hlm. 73 kesatuan sistem yang terdiri dari rangka landasan, bagian-bagian motor penggerak, perangkat penerus daya, bodi kendaraan, perangkat rem, perangkat suspensi atau roda, perangkat kemudi beserta kelistrikan yang saling mengadakan Inter relasi secarat tertib.

Dalam Peraturan Menteri Perhubungan Nomor 133 Tahun 2015 tentang Pengujian Kendaraan Bermotor pada Pasal 1 menjelaskan pengujian berkala kendaraan bermotor yang selanjutnya disebut uji berkala adalah pengujian kendaraan bermotor yang dilakukan secara berkala dalam 6 (enam) bulan sekali terhadap setiap kendaraan bermotor, kereta gandengan, dan kereta tempelan dan kendaraan khusus. Pengujian kendaraan bermotor ini dilaksanakan untuk mengawasi kondisi teknis kendaraan bermotor itu sendiri agar senantiasa dalam kondisi laik jalan.

Tujuan dari pelaksanaan pengujian kendaraan bermotor adalah: 1. Penyelenggaraan pengujian kendaraan bermotor yang dilakukan secara berkala mempunyai tujuan supaya menjaga agar kendaraan tersebut tidak mengandung kekurangankekurangan secara teknis yang diketahui/tidak sehingga menimbulkan bahaya bagi masyarakat dan lingkungan.

2. Hasil daripemeriksaan pengujian kendaraan bermotor ini dapat dipertanggung jawabkan. 
3. Menjaga prasarana lalu lintas seperti jalan raya dan jembatan agar tidak cepat rusak.

Sasaran dari penyelenggaraan pemeriksaan pengujian kendaraan bermotor ini yaitu ditujukan pada kendaraan wajib uji yaitu mobil penumpang umum, mobil bus, mobil barang, kereta tempelan dan kereta gandengan dan dilaksanakan oleh Pemerintah Daerah dalam hal ini Instansi Perhubungan.

\subsection{Pelaksanaan Uji Kelayakan Kendaraan Bermotor di Kota Denpasar}

Sebagaimana telah di uraikan sebelumnya, pengertian pelayanan pengujian kendaraan adalah pelayanan pengujian kendaraan bermotor yang sesuai dengan peraturan perundangundangan, dan diselenggarakan oleh pemerintah daerah. Pelayanan pengujian kendaraan bermotor di sini menyangkut kelaikan kendaraan yang dikenal dengan uji kendaraan bermotor dan dilaksanakan oleh pemerintah daerah dalam hal ini instansi Dinas Perhubungan Kota Denpasar.

Dalam prosesnya, prosedur pengujian kendaraan bermotor pada UPT Pengujian Kendaraan Bermotor Kota Denpasar dilakukan melalui 2 (dua) tahapan, yaitu proses administrasi dan proses pemeriksaan teknis laik jalan kendaraan bermotor. Pada proses administrasi, syarat-syarat yang harus dipenuhi oleh pemilik kendaraan sebelum dilakukan pemeriksaan teknis pada unit pengujian kendaraan bermotor adalah dengan melampirkan Buku Uji dan Surat Tanda Nomor Kendaraan (STNK) dan Kartu Tanda Penduduk (KTP), Ijin Operasional Asli dan Surat Ijin Usaha Angkutan(Khusus untuk kendaraan umum), dan Surat Tera (Khusus untuk kendaraan Tangki BBM) yang diletakkan dalam 1 map. Sedangkan dalam proses pemeriksaan teknis laik jalan kendaraan bermotor yaitu dilakukan kegiatan memeriksa, mencoba dan meneliti yang diarahkan kepada setiap kendaraan bermotor yang wajib uji berkala secara keseluruhan pada bagian-bagian kendaraan secara fungsional dalam sistem komponen serta dimensi teknis kendaraan bermotor baik berdasarkan ketentuan yang berlaku maupun berdasarkan ketentuan persyaratan teknis yang objektif.Prosespemeriksaankendaraan bermotor di UPT Pengujian Kendaraan Bermotor Kota Denpasar meliputi :

1. Pemeriksaan uji emisi gas buang, dimana pemeriksaan ini bertujuan untuk melihat apakah emisi yang dikeluarkan sudah melewati ambang batas yang ditentukan atau belum. Kendaraan bermotor yang wajib uji berkala untuk memenuhi ambang batas laik jalan yang sesuai dengan ketentuan Peraturan Pemerintah No. 55 Tahun 2012 tentang Kendaraan pada Pasal 65.

2. Pemeriksaan pada alat uji Head Light Tester meliputi: 
a) Lampu Utama, Lampu dekat dan intensitasnya

b) Penyimpangan arah lampu utama.

3. Pemeriksaan pada alat uji Side Slip Tester, disini kendaraan diperiksa slip samping roda depan.

4. Pemeriksaan pada alat uji Speedometer Tester, pada alat uji ini kendaraan diperiksa apakah kecepatannya sesuai dengan Speedometer yang ada pada kendaraan tersebut.

5. Pemeriksaan pada alat uji Brake Tester, pada alat ini kendaraan yang diperiksa adalah efisiensi rem utama baik sumbu depan maupun sumbu belakang.

6. Pemeriksaan pada alat uji Under Cariage dan Joint playing detector, pada alat uji yang berfungsi untuk memeriksa bagian bawah kendaraan bermotor.

Dari pengujian yang telah dilakukan akan mendapatkan hasil kendaraan yang di uji lolos atau tidak. Bagi kendaraan yang dinyatakan lulus uji mendapat perpanjangan buku uji berkala selama 6 (enam) bulan dan dilengkapi dengan tanda samping atau tanda uji berkala, yaitu berat kosong kendaraan, jumlah berat yang diperbolehkan atau diizinkan, daya angkut barang, masa berlaku surat/ tanda uji dan kelas jalan terendah yang boleh dilalui. Buku uji tersebut memuatketerangan tentang identifikasi kendaraan bermotor dan identitas pemilik, spesifikasi teknis, hasil uji, dan masa berlaku hasil uji. Sedangkan tanda uji berkala memuat keterangan tentang identifikasi kendaraan bermotor dan masa berlaku hasil uji. Apabila kendaraan yang diuji tidak lolos uji, maka harus disampaikan secara tertulis disertai dengan :

1). Alasan tidak lulus uji;

2). Item yang tidak lulus uji;

3). Perbaikan yang harus dilakukan; dan

4). Batas waktu mengajukan pengujian ulang.

Dalam Peraturan Daerah

Kota Denpasar Nomor 20 Tahun 2011 tentang Retribusi Pengujian Kendaraan Bermotor pada Pasal 8, ada 5 (lima) jenis atau kategori pelayanan pengujian kendaraan bermotor pada UPT. Pengujian Kendaraan Bermotor Kota Denpasar antara lain :

1). Pengujian Pertama;

2). Pengujian Berkala;

3). Numpang Uji Masuk;

4). Numpang Uji Keluar; dan

5). Mutasi Masuk Dari Wilayah Lain.

\subsection{Pelaksanaan Pengujian Kendaraan Bermotor Sebagai Wujud Keselamatan Berlalu Lintas}

Dewasa ini, kendaraan bermotor tidak hanya dipandang sebagai hasil rekayasa teknologi semata, namun dalam perannya sebagai sarana transportasi, kendaraan bermotor 
juga mampu berpotensi menimbulkan kecelakaan lalu lintas. Dengan keadaan yang demikian tentunya penggunaan kendaraan bermotor sebagai alat transportasi yang dioperasikan di jalan perlu mendapat perlakuan yang baik dan benar dalam penggunaannya. Sebagaimana kita ketahui bahwa lalu lintas dan angkutan jalan merupakan interaksi atau hubungan dari 3 (tiga) faktor utama yakni jalan, manusia dan kendaraan bermotor. Untuk mewujudkan kondisi lalu lintas dan angkutan jalan yang aman dan selamat, ketiga faktor tersebut haruslah memenuhi aspek kelaikan, antara lain manusianya harus laik kemudi, jalan yang dilintasi harus laik lintas dan yang tidak kalah pentingnya adalah kendaraan bermotor yang digunakan harus laik jalan

Dengan demikian, apabila setiap kendaraan bermotor mempunyai potensi dapat mencelakakan orang lain serta setiap kendaraan bermotor serta mempunyai potensi untuk mencemari lingkungan hidup seharusnya setiap kendaraan bermotor wajib memenuhi persyaratan teknis dan laik jalan. Untuk memastikan bahwa setiap kendaraan bermotor telah memenuhi persyaratan teknis dan laik jalan, wajib dilakukan pengujian kendaraan bermotor.

Berdasarkan wawancara dengan Bapak Dewa Sutardja, selaku Kepala UPT PKB Kota Denpasar (wawancara pada tanggal 24 Januari 2017), menurut beliau pada prakteknya pemeriksaan kendaraan dengan pengujian kendaraan bermotor ini mempunyai peran dan manfaat sebagai berikut: ${ }^{13}$

1. Mencegah atau memperkecil kemungkinan terjadinya kecelakaan lalu lintas, kebakaran, pencemaran lingkungan, kerusakan-kerusakan berat pada waktu pemakaian.

2. Kendaraan bermotor yang lulus uji telah melalui serangkaian pemeriksaan dengan peralatanperalatan mekanis akan terdeteksi dini tentang adanya kerusakan-kerusakan teknis sehingga tidak terjadi halhal yang membahayakan atau kecelakaan. Misalnya ketika efisiensi rem setelah diuji dengan brake tester hanya menunjukkan $40 \%$ padahal menurut ketentuan yang berlaku minimal adalah $50 \%$, sehingga secara teknis sangat mungkin terjadi rem blong ketika kendaraan bermotor telah beroperasi di jalan.

3. Pemeriksaan emisi gas buang dimaksudkan untuk mencegah terjadinya pencemaran udara, oleh karena itu, terhadap kendaraan mesin diesel misalnya dipersyaratkan maksimal $50 \%$ opasitas ketebalan asap.

4. Memberikan informasi kepada pengusaha atau pemilik kendaraan bermotor tentang daya angkut kendaraan, Muatan

13 Dewa Sutardja (selaku Kepala Unit Pelaksana Teknis Dinas Perhubungan Kota Denpasar, wawancara dilakukan pada hari selasa, 24 Januari 2017). 
Sumbu Terberat serta Kelas jalan yang terendah yang dapat dilalui.

5. Setiap kendaraan yang diuji akan diukur kemampuan daya angkut maupun MST serta dipertimbangkan dari kelas jalan terendah yang akan dilalui berikut kemampuan ban yang tersedia, sehingga dapat mencegah terjadinya kerusakan jalan dan jembatan maupun kendaraan itu sendiri (dengan prasyarat pengusaha atau pemilik mematuhi ketentuan daya angkut yang diberikan).

6. Memberitahukan kondisi kendaraan, dan apabila ada kerusakan makan harus memberikan pula saran untuk perbaikan kendaraan kepada pengusaha atau pemilik kendaraan mengenai kondisi kendaraannya.

7. Ketika diketahui terdapat penyimpangan dari standar atau ambang batas yang telah ditentukan dan diperkirakan dapat berakibat fatal maka disarankan perbaikan-perbaikan yang harus dilaksanakan sebelum terjadi kerusakan yang lebih besar. Misalnya dalam hal kecil saja seperti lampu, apabila dibiarkan mati dapat membahayakan diri dan juga pengguna jalan lainnya.

Dalam wawancara dengan pemilik kendaraan yang sedang melakukan uji kir, yaitu Bapak Martin Senayadi, dengan ia melakukan pengujian kendaraan bermotor nya, selain untuk memenuhi persyaratan kendaraannya supaya laik jalan, ia juga dapat mengetahui kondisi kendaraannya apakah seluruh komponen di kendaraannya baik atau ada yang rusak, sehingga apabila ia melakukan perjalanan jauh, tidak akan merasa waswas. ${ }^{14}$

Wawancara kedua dengan Bapak Rai Suardana. pemilik kendaraan yang juga melakukan uji berkala kendaraan bermotor nya mengatakan, kendaraan bermotor nya sering digunakan untuk bekerja mengantar tamu Warga Negara Asing berkeliling menuju tempat wisata-wisata yang ada di Bali, dengan ia melakukan pengujian kendaraannya, selain untuk dapat mengetahui kondisi kendaraannya serta untuk melengkapi persyaratan dalam hal kendaraan laik jalan juga untuk meminimalisir gangguan yang terjadi apabila sedang berkendara jauh sehingga tidak mengganggu kenyamanan warga negara asing yang dibawanya. ${ }^{15}$

Dengan demikian, sistem pengujian yang baik dapat mewujudkan kondisi sistem transportasi yang baik pula yaitu sebagai berikut:

14 Martin Senayadi (masyarakat, selaku pemilik kendaraan yang melakukan pengujian kendaraan bermotor, wawancara dilakukan pada hari Jumat, 27 Januari 2017).

15 Rai Suardana (masyarakat, selaku pemilik kendaraan yang melakukan pengujian kendaraan bermotor, wawancara dilakukan pada hari Jumat, 27 Januari 2017). 
1. Dapat meningkatnya efisiensi mengenaibiaya transportasi yang berhubungan dengan mobilitas manusia dan barang;

2. Minimalnya distorsi kelancaran lalu lintas jalan dikarenakan jaminan terhadap kelaikan jalan dari seluruh kendaraan bermotor yang telah beroperasi di jalan;

3. Mengurangi tingkat kecelakaan lalu lintas yang diakibatkan oleh faktor teknis dari kendaraan bermotor;

4. Terkendalinya pencemaran lingkungan yang diakibatkan oleh emisi gas buang kendaraan bermotor;

5. Merangsang penggunaan bahan bakar yang aman bagi kesehatan dan lingkungan;

6. Tersosialisasinya kriteria laik jalan padapenggunaankendaraan bermotor di jalan;

7. Rangsangan terhadap perkembangan teknologi

kendaraan bermotoryang relevan terhadap standar kelaikan jalan yang ditentukan, dikarenakan tuntutan kebutuhan pasar dan regulasi yang berkembang secara dinamis; dan

8. Berkembangnya sistem pengujian kendaraan bermotor yang sejalan dengan harmonisasi sistem pengujian kendaraan bermotor secara global.

Dengan melihat manfaat yang ditimbulkan dengan kendaraan bermotor melakukan pemeriksaan pengujian kendaraan bermotor nya, pengujian kendaraan bermotor merupakan langkah strategis dalam meningkatkankeselamatantransportasi jalan dan turut mewujudkan kondisi zero accident, diantaranya dengan menerapkan jaminan keselamatan penggunaan sarana angkutan agar memenuhi persyaratan teknis dan laik jalan kendaraan.

Terkait dengan adanya jaminan keamanan serta keselamatan secara teknis terhadap penggunaan kendaraan bermotor dijalan, untuk itu diperlukan pengujian kendaraan secara cermat yang dilakukan oleh tenaga yang profesional sesuai dengan ketentuan yang berlaku. Dengan demikian pelaksanaan pengujian kendaraan bermotor dapat dijadikan salah satu unsur kekuatan penyeimbang atau countervailing power dampak negatif yang ditimbulkan oleh kemajuan teknologi di sektor transportasi.

\section{KESIMPULAN}

Dari pembahasan yang sudah dipaparkan diatas, oleh karena itu kesimpulan yang didapat adalah :

1. Pelaksanaan uji kelayakan kendaraan bermotor oleh Dinas Perhubungan Kota Denpasar dilakukan melalui 2 (dua) tahapan,yaituprosesadministrasi dan proses pemeriksaan teknis laik jalan kendaraan bermotor. Dalam proses pemeriksaan teknis laik jalan, meliputi kegiatan memeriksa, mencoba dan 
meneliti diarahkan kepada setiap kendaraan bermotor yang wajib uji berkala secara keseluruhan pada bagian-bagian kendaraan secara fungsional dalam sistem komponen serta dimensi teknis kendaraan bermotor baik berdasarkan ketentuan yang berlaku maupun berdasarkan ketentuan persyaratan teknis yang objektif. Pemeriksaan di Dinas Perhubungan Kota Denpasar meliputi:

a. Pemeriksaan uji emisi gas buang.

b. Pemeriksaan Head Light Tester meliputi lampu utama, lampu dekat dan intensitasnya serta penyimpangan arah lampu utama.

c. Pemeriksaan Side Slip Tester, yaitu kendaraan diperiksa pada slip samping roda depan.

d. Pemeriksaan Speedometer Tester, yaitu pemeriksaan kecepatan yang disesuaikan dengan speedometer pada kendaraan tersebut.

e. Pemeriksaan Brake Tester, yaitu pemeriksaan efisiensi rem utama baik sumbu depan maupun sumbu belakang.

f. Terakhir pemeriksaan Under Cariage dan Joint playing detector, yaitu memeriksa bagian bawah kendaraan bermotor.
Dari pengujian yang telah dilakukan akan mendapatkan hasil kendaraan yang di uji lolos atau tidak. Bagi kendaraan yang dinyatakan lulus uji mendapat perpanjangan buku uji berkala selama 6 (enam) bulan dan dilengkapi dengan tanda samping atau tanda uji berkala, sedangkan apabila tidak lulus uji maka disampaikan secara tertulis disertai dengan alasan tidak lulus uji, item yang tidak lulus uji, perbaikan yang harus dilakukan dan batas waktu mengajukan pengujian ulang.

2. Mengenai pelaksanaan pengujian kendaraan bermotor dalam mewujudkan keselamatan berlalu lintas, setelah melakukan wawancara dengan Kepala UPT Pengujian Kendaraan Bermotor Kota Denpasar dan masyarakat wajib uji mengatakan bahwa tujuan dilakukannya uji kendaraan bermotor adalah selain sebagai syarat kendaraan laik jalan juga untuk mencegah atau memperkecil kemungkinan terjadinya kecelakaan lalu lintas, kebakaran, pencemaran lingkungan, kerusakankerusakan berat pada waktu pemakaian dan ketika diketahui terdapat penyimpangan dari standar atau ambang batas yang telah ditentukan dan diperkirakan dapat berakibat fatal maka disarankan perbaikan-perbaikan 
yang harus dilaksanakan sebelum terjadi kerusakan yang lebih besar. Dengan pemeriksaan yang dilakukan serta saransaran apabila ditemukan adanya kerusakan dalam kendaraan yang diuji, diharapkan untuk bisa meminimalisir terjadinya kecelakaan lalu lintas yang disebabkan oleh kendaraan. Dilanjutkan wawancara dengan para pelaku wajib uji atau pemilik kendaraan yang melakukan pengujian kendaraan bermotor

\section{DAFTAR PUSTAKA}

Buku:

Darise, Nurlan, 2006, Pengelolaan Keuangan Daerah. PT. Indeks, Jakarta.

Fajar, Mukti \& Yulianto Achmad, 2010, Dualisme Penelitian Hukum Normatif \& Empiris, Pustaka Pelajar, Yogyakarta.

Nasution, Bahder Johan, 2008, Metode

Penelitian Ilmu Hukum, Mandar Maju, Bandung.

Pontoh, Nia Kurniasih dan Iwan Kustiawan, 2009, Pengantar Perencanaan Perkotaan, Bandung: Institut Teknologi Bandung.

\section{Artikel Majalah Ilmiah}

Aditya Wiryadarma, I Made dan I Gusti Ngurah Wairocana, 2015, Penegakkan Peraturan Daerah Kota Denpasar Nomor 26 Tahun 2001 Tentang Penyelenggaraan
Pengujian Kendaraan Bermotor, E-Jurnal Manajemen Unud, Vol. 3, No. 3, 2015, http://ejournal. an.fisip-unmul.ac.id/site/ wpcontent/uploads/2013/11/02_ format_artikel_ejournal_mulai_ hlm_genap\%20(11-27-13-0700-58.pdf, diakses pada tanggal 3 September 2017.

Anggia Paramesthi Fajar, Ni Made, 2015, Pelaksanaan Peraturan Daerah Provinsi Bali No 5 Tahun 2008 Tentang Pramuwisata di Kabupaten Badung, Jurnal Magister Hukum Udayana (Udayana Master Law Journal), vol. 4 no. 2 edisi Juli 2015.

Daniel, 2013, Studi Tentang Pelayanan dan Pengujian Kelaikan Kendaraan Bermotor di UPT. Pengujian Kendaraan Bermotor Dinas Perhubungan Kota Samarinda, eJournal Administrasi Negara, 2013, 1 (4): 1554-1568, http://ejournal. an.fisip-unmul.ac.id/site/ wpcontent/uploads/2013/11/02_ format_article_ejournal_mulai_ hlm_genap $\% 20$ (11-27-13-070058), diakses pada tanggal 3 September 2017.

Dwi Chantika, Otovinur, 2013, Kinerja Organisasi UPTD Pengujian Kendaraan Bermotor Wiyung Kota Surabaya, Volume 1 Nomor 1 Januari 2013, http:// juornal.unair.ac.id/downloadfullpapers-2\%20Otovinur $\% 2$ 0KMP\%20VI\%20NI\%20Jan- 
April\%202013.pdf, diakses pada tanggal 3 September 2017.

Komang Surya Dharma Putra, Ida Bagus dan Agoes Ganesha Rahyuda, 2015, Pengaruh Lingkungan Kerja Fisik dan Stres Kerja Terhadap Kinerja Pegawai di UPT. Pengujian Kendaraan Bermotor Dinas Perhubungan Kota Denpasar, E-Jurnal Manajemen Unud, Vol. 4, No. 9, 2015, https://ojs,unud. ac.id/index.php/Kerthanegara/ article/view/15203, diakses pada tanggal 3 September 2017.

Nazifah, Ainun dan Ernawati, Kinerja Dinas Perhubungan Komunikasi danInformastikaKotaPekanbaru Dalam Melakukan Pemeriksaan Angkutan Kota (Uji Kir), Fisip Universitas Riau, https://jom. unri.ac.id/index.php/JOMFSIP/ aricle/viewFile/2214/2156, diakses pada tanggal 3 September 2017.

\section{Peraturan Perundang-Undangan}

1. Undang-Undang Republik Indonesia Nomor 22 Tahun 2009 tentang Lalu Lintas dan Angkutan Jalan (Lembaran Negara Republik Indonesia Tahun 2009 Nomor 96, Tambahan Lembaran Negara Republik Indonesia Nomor 2025).

2. Peraturan Pemerintah Nomor 55 Tahun 2012 tentang Kendaraan (Lembaran Negara Republik Indonesia Tahun 2012 Nomor
120, Tambahan Lembaran Negara Republik Indonesia Nomor 5317).

3. Peraturan Menteri Perhubungan Nomor 133 Tahun 2015 tentang Pengujian Kendaraan Bermotor (Berita Negara Republik Indonesia Tahun 2015 Nomor 1296)

4. Peraturan Daerah Kota Denpasar Nomor 20 Tahun 2011 tentang Retribusi Pengujian Kendaraan Bermotor (Lembaran Daerah Kota Denpasar Tahun 2011 Nomor 20, Tambahan Lembaran Daerah Kota Denpasar Nomor 20). 